\title{
Common Bark Beetle Pests of Florida ${ }^{1}$
}

\author{
Sawyer Adams and Jiri Hulcr²
}

This guide was created specifically as an aid for youth forestry knowledge competitions, including 4- $\mathrm{H}$ and Future Farmers of America. Along with a collection of the listed beetles, it is suitable as a beginner's introduction to the most important pine pests in Florida. These materials do not serve as a standalone identification guide.

\section{Bark and Ambrosia Beetles- Overview}

Bark and ambrosia beetles are a diverse group of beetles that can be found boring into and living in trees throughout the forest. While many of them are beneficial and feed only on dead trees, some bark and ambrosia beetles can become invasive and kill the trees they live in when introduced to new areas through human transport of wood products. Bark beetles feed on the nutrient-rich phloem. The few species of bark beetle that attack living trees overwhelm the tree defenses by attacking in large numbers. Ambrosia beetles are very interesting organisms because they carry fungal spores in an organ on their body called a mycangium. Once they burrow into a tree, the spores from the mycangium grow into fungi, which the beetles and their offspring feed on. This makes ambrosia beetles an insect that farms its own food! However, this also makes invasive ambrosia beetles even more dangerous because the fungi they carry can infect and kill the tree.

Because we need to be on the lookout for invasive bark and ambrosia beetles in our forests, it is important that we be able to identify them.

\section{Characteristic Features of Bark and Ambrosia Beetles:}

- Cylindrical bodies

- Very small, always less than $1 \mathrm{~cm}$

- Bent antennae with a club at the end

- Large, round head partially hidden in pronotum

- Pronotum-a hard plate that covers the thorax of an insect (in bark and ambrosia beetles, the head emerges from underneath the pronotum)
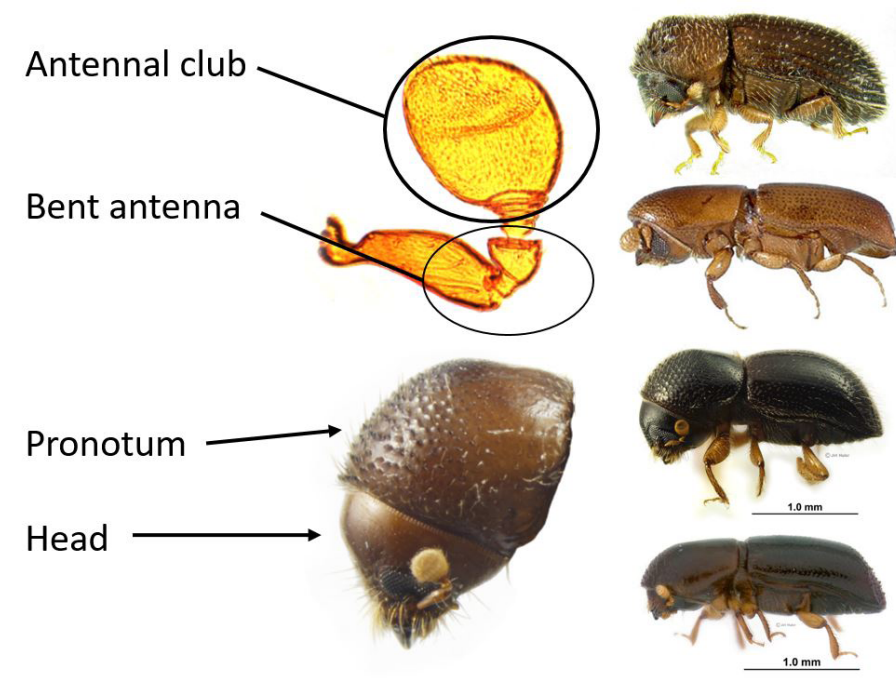

Figure 1. Bark and ambrosia beetle anatomy. Credits: Jiri Hulcr, UF/IFAS

1. This publication is $4 \mathrm{H} 417$, one of a series of the $4-\mathrm{H}$ Youth Development Program, UF/IFAS Extension. Original publication date September 2021. Visit the EDIS website at https://edis.ifas.ufl.edu for the currently supported version of this publication.

2. Sawyer Adams, lab manager, and Jiri Hulcr, associate professor, forest entomology, Entomology and Nematology Department and School of Forest, Fisheries, and Geomatics Sciences; UF/IFAS Extension, Gainesville, FL 32611.

The Institute of Food and Agricultural Sciences (IFAS) is an Equal Opportunity Institution authorized to provide research, educational information and other services

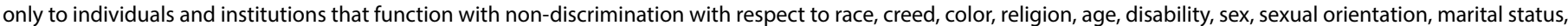

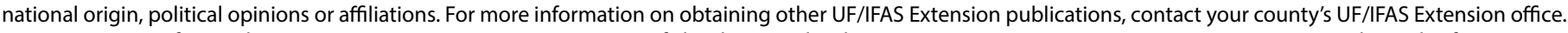
U.S. Department of Agriculture, UF/IFAS Extension Service, University of Florida, IFAS, Florida A \& M University Cooperative Extension Program, and Boards of County Commissioners Cooperating. Nick T. Place, dean for UF/IFAS Extension. 


\section{Black Turpentine Beetle}

\section{Dendroctonus terebrans}

- Large (5-8 mm)

- Largest of the bark beetles in the southeastern United States

- Rounded posterior

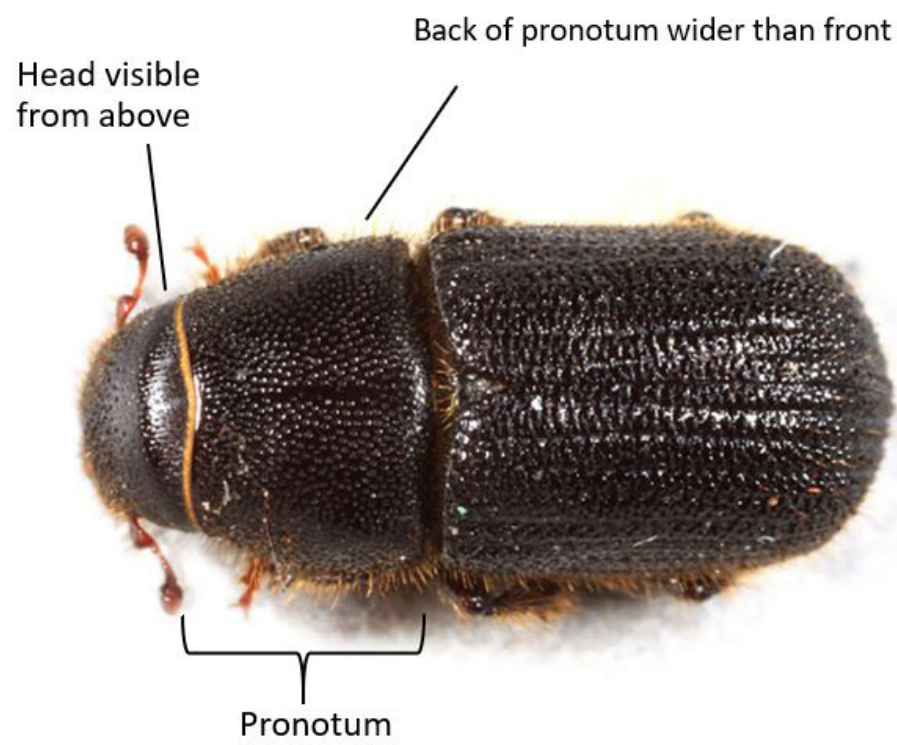

Figure 2. Black turpentine beetle.

Credits: Jiri Hulcr, UF/IFAS

\section{Southern Pine Beetle}

\section{Dendroctonus frontalis}
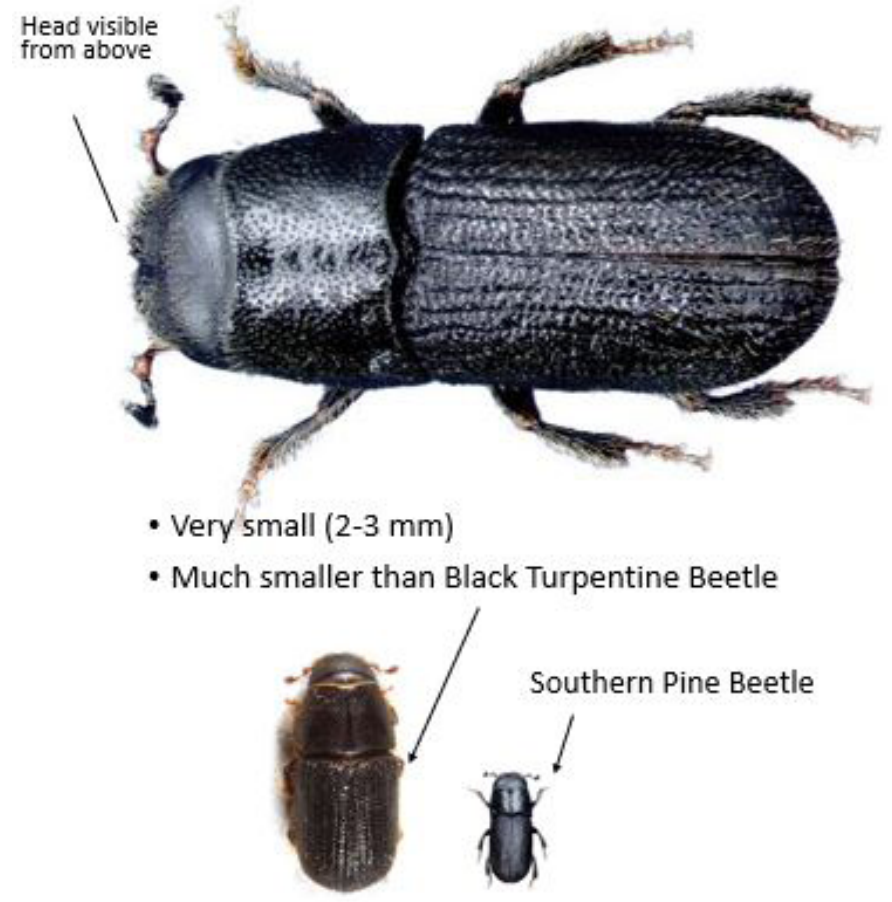

Figure 3. Southern pine beetle.

Credits: Jiri Hulcr, UF/IFAS

\section{Ips Engraver Beetles \\ Ips species}

- "Crown" of protrusions on hind end

- Three species of different sizes

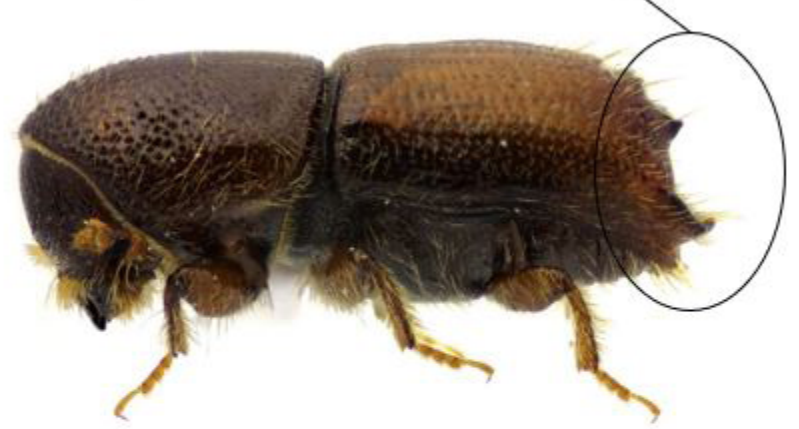

Head is concealed when seen from above

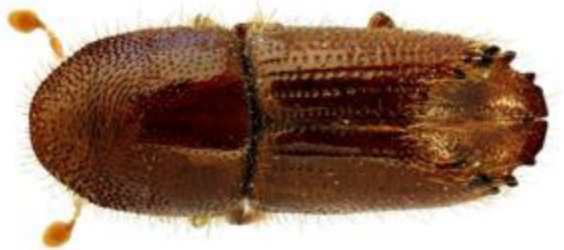

Figure 4. Ips engraver beetle.

Credits: Jiri Hulcr, UF/IFAS 


\section{Ambrosia Beetles}

\section{Many Species}

- Usually tiny (less than $3 \mathrm{~mm}$ )

- Related to bark beetles, but feed on fungus inoculated into trees

\section{Redbay ambrosia beetle}

- Dark and shiny, pointed posterior

- Spreads a pathogen of redbays and avocados

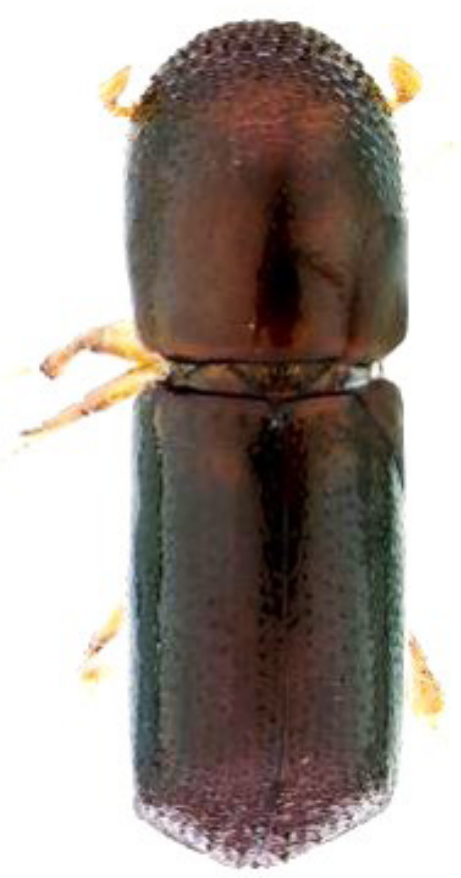

Figure 5. Redbay ambrosia beetle.

Credits: Jiri Hulcr, UF/IFAS

\section{Granulated ambrosia beetle}

- Orange/red color

- Rough posterior

- Tree nursery pest

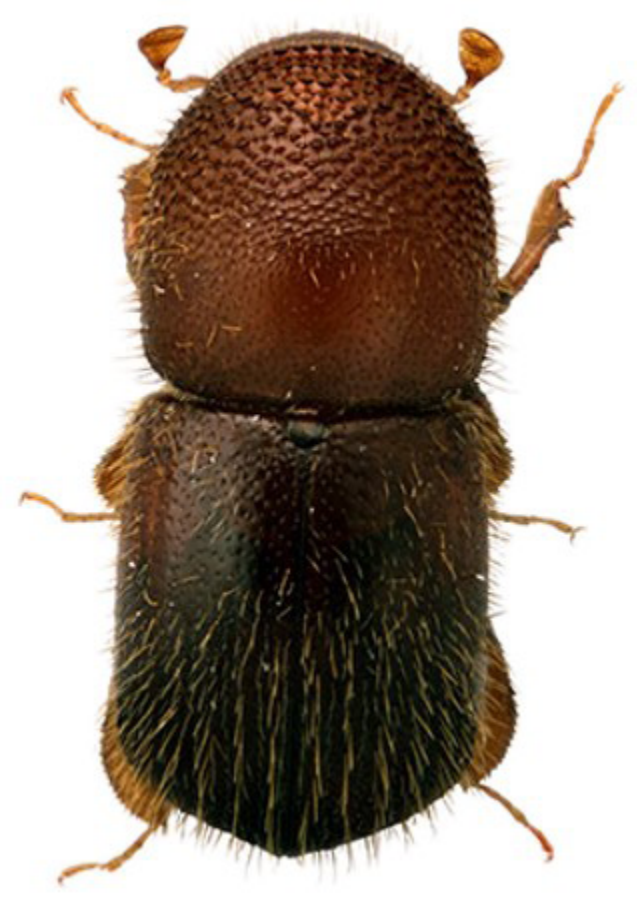

Figure 6. Granulated ambrosia beetle. Credits: Jiri Hulcr, UF/IFAS 


\section{Reproduction Weevils}

\section{Hylobius pales \& Pachylobius picivorus}

- 8-12 mm

- Sometimes have scattered light patches, or are solid black

- Long snout and legs

- True weevil, not a bark beetle

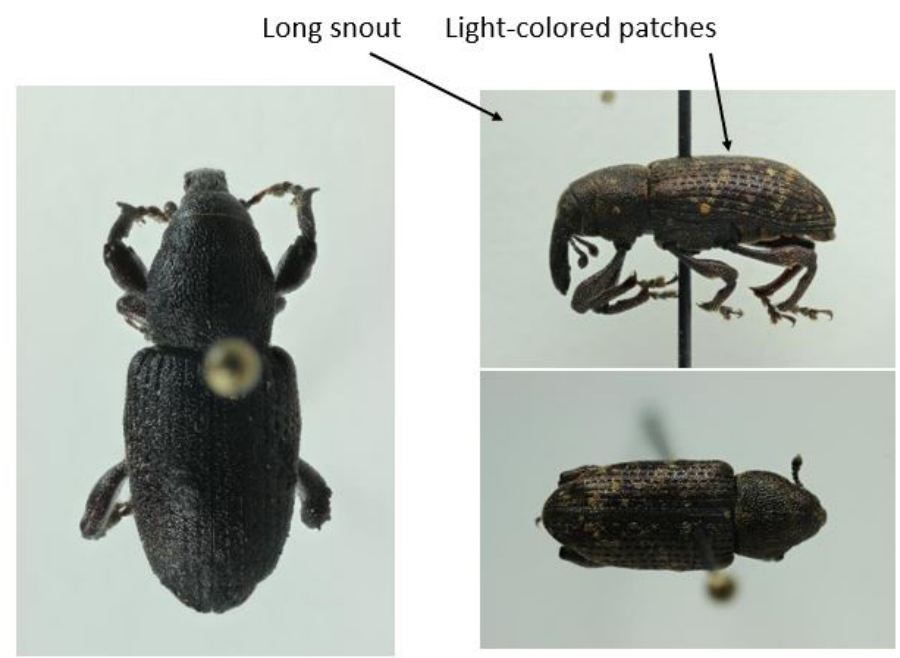

Figure 7. Reproduction weevils. Credits: Sawyer Adams, UF/IFAS

\section{Longhorn Beetle, Pine Sawyer}

Monochamus spp.

- Large, long antennae

- Note that the antennae are not clubbed and not bent

- Long legs

- Larvae chew in dead wood

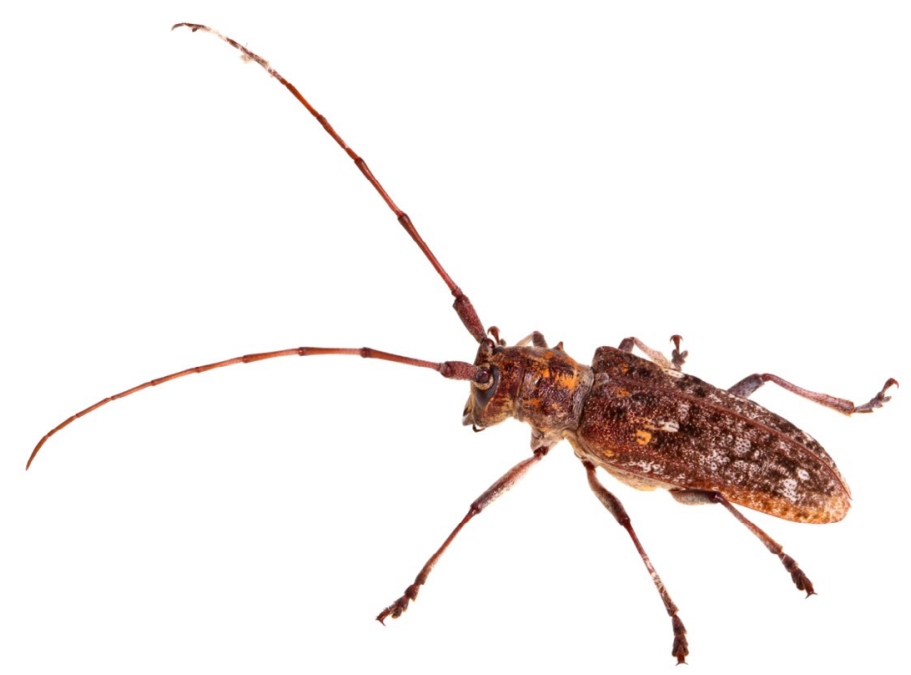

Figure 8. Longhorn beetle.

Credits: Stephen Goodwin/Alamy Stock Photo 